DOI 10.31558/2519-2949.2020.3.2

УДК 321.011 .5

ORCID ID: https://orcid.org/0000-0002-1004-3165

Гапоненко В. А., Національний педагогічний університет

ім. М. П. Драгоманова

\title{
НЕКОНВЕНЦИЙНІ ФОРМИ ПРОТЕСТУ В УКРАЇНІ: МЕХАНІЗМ ІНСТИТУЦІЙНИХ ЗМІН ЧИ МАНІПУЛЯТИВНА ТЕХНОЛОГІЯ?
}

У статті розкриваються особливості неконвенційного протесту в умовах демократизаиії політичної системи Украӥни. Уточнюється сутність поняття «не конвенційний протест» в контексті прочесів утвердження гібридного режиму. Розкривається суперечлива роль політичної участі як механізму впливу на владу, рушійної сили реформ та, водночас, технологія маніпулювання масами, наслідок боротьби за владу впливових політичних акторів. Також аналізується здатність неконвениійного протесту сприяти трансформаиії гібридної інституційної системи.

Доведено схильність політичних еліт використовувати мобілізацію масових протестів для досягнення вузькокорпоративних иілей та залежність успіху протестів від волі представників політичної еліти. Обтрунтовано інституиійне утвердження протестної практики боротьби за владу. Вказано на тенденцію зростання неорганізованих виступів та посилення неконвенційної складової протестів в Україні внаслідок недовіри до політичних інститутів, а також радикалізацію суспільно-політичних настроїв.

Розглядаються причини та наслідки наймасштабніших неконвенційних протестів в історії України в контексті їхнього впливу на процеси демократизаиї політичної системи. Відзначається поверховий половинчастий характер інституційних змін внаслідок народних протестів, що здебільшого, сприяли зміні влади, тимчасовому зняттю соціальної напруженості. Натомість інституційна система практично не зазнавала змін, утверджуючи не конвенційний протест як єдино можливий варіант ефективної політичної участі.

Серед причин періодичного повторення масових неконвениійних протестів вказано на їхню інституційну зумовленість та сприйняття як дісвого та внормованого методу впливу на владу. Обтрунтовано виникнення неконвенційних форм протесту у зв'язку з відсутністю дієвих механізмів інституиіоналізованого впливу на владу, слабкості або заангажованості інститутів громадянського суспільства, неефективності механізмів представниитва інтересів, внаслідок чого акиї̈ громадянської непокори, попри демократичну спрямованість, призводять до утвердження гібридного режиму і домінування неформальних деструктивних інститутів.

Ключові слова: політична участь, політична система, демократизачія, інституційні зміни, політичний протест, громадянська непокора, не конвениійний протест.

Політична участь - це визнаний інститут демократії та народовладдя. Вона допускає різні форми громадянської непокори проти політичних рішень та дій представників влади. В умовах розвиненої демократії цей протест має дозволені конвенційні форми, що зумовлює виконання ряду позитивних для розвитку політичної системи функцій. Розробці цього питання присвячені праці таких класиків політичної науки як Б. Барбер [1], Е. Гутман [2], Р. Пантам [3].

Набагато складніше оцінити роль політичного протесту в умовах неінституціоналізованої демократії та гібридного політичного режиму. Більшість пост авторитарних політичних систем стали наслідком народного невдоволення. Однак, у подальшому державному будівництві не конвенційні протести, утверджуючись як механізм політичної участі, чинить скоріше деструктивний вплив на систему демократичних інститутів.

Теоретичне осмислення проблеми не конвенційних форм політичного протесту набуває особливої популярності в Україні узв'язку з рядом масових акцій громадянської непокори у вітчизняній історії, сучасними тенденціями радикалізації протестів. Зокрема, виявленню сучасних передумов неконвенційних протестів присвячують свої наукові публікації Є. Васильчук [4], 
Н. Грищенко [5], а інституційний підхід вивчення не конвенційного протесту застосовують Г. Зеленько [6], А. Колодій [7], А. Романюк [8]. Водночас, подальшого дослідження потребують проблеми виявлення ролі не конвенційного протесту для демократизації у гібридній інституційній системі.

Звертаючись до теоретичних засад дослідження політичного протесту, слід звернути увагу на неоднозначність розуміння «неконвенційної» (незаконної) участі. Часто конвенційні та не конвенційні аспекти протесту тісно взаємопов'язані, перетікають одна в одну. Оцінка протестних дій може відрізнятись в залежності від типу політичної системи, прийнятих суспільних норм, їх результатів та наслідків. Тому до не конвенційних форм протесту відносимо будь-які стихійні виступи проти всієї системи влади: мітинги, демонстації, страйки, голодування.

Майже аксіомою політичної науки є теза про те, що неконвенційний протест виникає тоді, коли нема можливості по іншому вплинути на рішення влади $[7,8]$. Теж саме стосується пострадянських держав, в яких проголошені демократичні форми політичної участі мають формальний характер і виявляються недієвою.

Безперечною є також перевага інституціоналізованих форм протесту, що дозволяють утримувати акції громадянської непокори в рамках ненасильницьких дій, підвищувати їхню ефективність [6].

Водночас, варто звернути увагу на те, що в Україні, на додачу, політичний протест змінює наслідки підпорядкування формальним демократичним інститутом. У такий спосіб він слугує одним 3 механізмів утвердження гібридного режиму. Тобто, не конвенційні протести виступають не лише компенсаторним механізмом політичної участі, а підміняють останню, роблять іï недієвою, підривають ії легітимність.

Проілюструємо такий висновок прикладами з політичної практики України. Вітчизняна історія демонструє принаймні чотири масштабні вияви не конвенційних протестів. Перша відбулась у 1990 р., отримавши назву «Революції на граніті». Учасники акції виступили проти всієї системи влади, виступивши з вимогами дострокового припинення повноважень Верховної Ради України та призначення нових виборів на багатопартійній основі восени 1991 р., відставки голови Ради Міністрів України Віталія Масола, прийняття закону про націоналізацію майна КПУ та ЛКСМУ; недопущення підписання нового Союзного договору; повернення в Україну солдатів, які проходять строкову службу за межами держави, і забезпечення проходження служби на території республіки юнакам подальших призовів [9].

Однак, згідно Постанови Верховної Ради УРСР [], повністю виконано була лише вимога відставки Віталія Масола. Інші пункти депутати зобов'язались виконати згодом.

Друга хвиля громадського незадоволення відбулась у формі загальнонаціонального страйку шахтарів 1993 р. Основні вимоги страйкуючих крім вирішення гострих соціально-економічних проблем, передбачали референдум щодо недовіри президенту та Верховної Ради і надання регіональної автономії Донбасу. У результаті шахтарських виступів нарешті відбулась зміна вищих органів державної влади, була частково погашена заборгованість по заробітній платі. Натомість замість підняття рівня мінімальної зарплати і решти соціальних вимог, задовольнили інтереси директорів шахт, зокрема надавши державні дотації на розвиток шахтарської галузі. Невирішеність цих питань багато років зберігала стан соціальної напруженості у Донбаському регіоні та нерентабельність економіки цілої галузі, що і на сьогодні дається в знаки.

Третю хвилю пов'язуємо з акціями «Україна без Кучми» 1999 р. Попри значно організованіший та інституціоналізований характер протестних дій (рух очолювали 24 політичні сили), мітингувальникам бракувало політичної програми. Вони вимагали відставки президента країни й керівників силових відомств, проведення незалежної експертизи у справі зниклого журналіста Георгія Гонгадзе. До поступового спаду акцій громадянської непокори призвів розкол у опозиції. Показовим у цьому випадку став документ, який у публіцистиці отримав назву Звернення трьох (президента Л.Кучми, голови ВРУ Плюща та прем'єр міністра В. Ющенка). Підпис В. Ющенка став несподіванкою, оскільки він асоціювався з конструктивною частиною опозиції, натомість виступив на стороні влади. У зверненні було засуджено дії мітингувальників та формулювався заклик до мирного врегулювання ситуації [11]. Як наслідок, акції громадянської непокори завершились проведенням показового референдуму на підтримку конституційних змін, які так і не були втілені в життя.

Четвертий етап боротьби за втілення демократичних реформ розпочався у 2004 р. через «Помаранчеву революцію». Ї̈і основною вимогою було недопущення результатів фальсифікації виборів. Вважаємо саме події 2004 р. найбільш організованими в історії українських протестів: 
керованими конкретними інститутами, що включали як представників парламентської опозиції, так і громадських організацій і рухів, супроводжувались агітаційною роботою, виробленням об'єднуючих символів, побутовим забезпеченням мітингувальників. Саме у результаті цього вдалося досягти чи не найглибших перетворень в країні. Так, відбувся перехід до парламентсько-президентської форми республіки. Вже до так званого третього туру виборів Президента України було внесено зміни до виборчого законодавства, змінено склад ЦВК.

Однак, як з'ясувалось в подальшому учасники акцій громадянської непокори прагнули набагато більшого, ніж було вміщено у найвідоміших лозунгах $2004 \mathrm{p}$. Зокрема, не було проведено належного розслідування у справі Г. Гонгадзе, ефективних антикорупційних заходів. Показова люстрація торкнулась лише адміністративного апарату органів державної влади, який має бути аполітичним за своєю природою, а тому це лише знизило якість управління. Розчарування у результатах Помаранчевої революції наростало через відсутність консенсусу серед правлячих еліт та боротьбою за владу.

Це призвело до не менш глибокого реваншу авторитарних сил, зокрема відміни конституційних змін у 2010 р., судові процеси над опозиційними лідерами Ю. Тимошенко та Ю. Луценком, що фактично стали новою для незалежної України практикою політичних репресій та підпорядкування судової гілки влади.

Також у 2010 р. відбувається зниження позицій української держави уряді рейтингів міжнародних дослідницьких організацій. Так, за показником індексу свободи Україна була виключена з категорії вільних держав [12] у зв'язку з централізацією влади, придушенням свободи слова в Україні, залякуванням неурядових організацій, нехтуванням засадами верховенства права, поширенням корупції, невільним судочинством, політичними репресіями та спотворенням і фальшуванням виборів. За рівнем свободи преси 2010р. Україна в рейтингу посіла 131-е місце замість 89-го у 2009 р. [13]. У 2011 р. Україна у рейтингу індексу демократії опустилась із 67-го на 79-те місце і була віднесена до категорії «гібридний режим» замість країни «з проблемною демократією» [14].

Нарешті, п'яту хвилю демократизації пов'язуємо з «Революцією гідності» та подіями 20132014 pp. Вона висунула вимоги підписання Угоди про Асоціацію з СС, відставки уряду та Президента, скликання позачергової сесії Верховної Ради, відміни «диктаторських законів» від 16 січня 2014 р., люстрації і звільнення Ю. Тимошенко.

Формально всі ці вимоги були виконані. Досягненнями Революції гідності стало відновлення Конституції у редакції 2004 р., Закон «Про очищення влади» тощо. Договір про Асоціацію було підписано. Але обіцяного поглиблення реформ так і не відбулося. Це зумовило нищівну поразку правлячих політичних сил на виборах 2019 р.

В цілому жодні зміни до Основного закону України та інших нормативних документів не змогли виключити дуалізму виконавчої влади та потенційного конфлікту між Президентом і Прем'єрміністром, забезпечити ефективне функціонування демократичних інститутів, гарантувати проголошені демократичні принципи. Тому всі народні виступи висували майже однакові вимоги: припинення сваволі влади, відновлення законних прав і свобод, зміна влади. Отже, конституційні норми не спрямовані на забезпечення стабільності, а мають поверховий формальний, популістський характер. Індикатором того, що на всіх етапах реформи проводились лише для «заспокоєння» громадськості може служити низький рівень виконання задекларованих всіма громадськими виступами цінностей.

Фактично у всіх випадках інституційні зміни сприяли, насамперед, ротаціям у владі, виконання вимог та досягнення інтересів впливових груп (політичної опозиції, олігархічної групи). Це посилює розчарування населення у здатності чинити вплив на перебіг подій. Рядові учасники революцій почуваються обманутими і не схильні брати участь у подальшій боротьбі. Наприклад, внаслідок виступів шахтарів посаду Глави уряду посів Ю. Звягільський, директор шахти. Інші директори отримали державні дотації на розвиток своїх підприємств.

Успіх акцій громадянської непокори напряму залежав від реакції правлячої еліти, ії готовності йти на компроміс. Це породжує грунт для розгляду акцій громадянської непокори як технології боротьби за владу, оскільки лояльне ставлення до протестних дій може бути розглянуто як зацікавленість в розхитуванні існуючого режиму. Саме такі мотиви пояснюють відсторонену позицію влади та незастосування сили проти мітингуючих. Так, Л. Кучма відкрито розігнав шахтарський страйк 1998 р., але виступив арбітром мирного врегулювання ситуації під час Помаранчевої революції. Очевидно, у другому випадку він вже змирився із втратою влади, а тому зберігав нейтралітет. 
Впадає в око дедалі більша кількість учасників акцій громадянської непокори, дедалі драматичніший розвиток подій, жорсткіший реванш і глибший рівень дестабілізації ситуації в державі. Участь у «Революції на граніті» взяло кілька сотень студентів, з них 137 тримали голодування. В акціях «Україна без кучми» 30 тисяч демонстрантів, a у Помаранчевій революції 5-6 млн. Безпрецедентним випадком в історії України стало застосування відкритого насильства під час протистояння у ході «Революції Гідності», Пов'язуємо його з неінституціоналізованим характером протистояння Адже, абсолютна більшість учасників Майдану (92 \%) не належала ані до якоїсь 3 партій, ані до громадських організацій та рухів [15]. Також важливо звернути увагу, що це був протест проти влади загалом, зокрема й опозиції. Нарешті, вирішальну роль у характері протистояння відіграла реакція влади, яка зробила ставку на силовий метод врегулювання ситуації, але програла.

Якщо у попередні періоди подолати наслідки масових протестів вдалося у мирний спосіб, то опосередкованим наслідком Революції гідності став сепаратистський рух та перманентний військовополітичний конфлікт. Така політична ситуація об'єктивно вимагає розширення повноважень військових структур, спецслужб, виконавчих органів, задіяних до вирішення конфлікту, обмеження частини індивідуальних прав і свобод, що становить загрозу деінституціоналізації демократії.

Аналізуючи причини виникнення сепаратизму, М. Хилько [16], звертає увагу на те, що воно має посттоталітарний характер, зумовлене неправильним сприйняттям права самовизначення, посилене невирішеними соціально-економічними проблемами та цілеспрямованою пропагандою певних угрупувань. Цілком погоджуємось 3 твердженням про те, що сепаратистський рух зумовлений диспропорційністю розвитку регіонів та неефективною регіональною політикою.

Крім сепаратистів, за останні роки активізували свою діяльність й інші радикальні угрупування. Їхню соціальну базу складають особи, що розчарувались повільними темпами реформ і шукають прості рішення складних проблем. Зокрема, почастішали організовані ультраправими рухами в Україні напади на ромів, представників ЛГБТ спільнот [17, с.35].

На період Революції гідності припадає формування радикального руху, що отримало в публіцистиці назву «тітушки». Спочатку їхня діяльність проявлялась в організації провокацій на заходах опозиційних до влади політичних сил, нападів на їхніх представників та громадських активістів, виборчих дільницях. Нині «тітушки» беруть участь у комерційних порахунках, рейдерських захопленнях, охороняють незаконні забудови за мовчазної згоди правоохоронних органів. [17, с.61].

Загалом неконвенційний протест в Україні набув характеру неформального акомодаційного інституту, що використовується як звична форма боротьби за владу, відстоювання власних інтересів, політичного управління. Однак, лояльне ставлення, а подекуди і потурання, політичного насильства суб'єктами політики призводить до делегітимації системи інститутів демократії, розчарування населення у можливості ефективної політичної участі.

Отже, до основних особливостей неконвенційного протесту в умовах демократизації політичної системи України відносимо відсутність ефективних альтернативних форм політичної участі, залежність успіху протесту від волі владарюючих суб'єктів, поверховий характер інституційних змін, що проводяться внаслідок масових виступів. Це доводить використання політичної участі як механізму імітації народовладдя та впливу на владу, технології маніпулювання масами та боротьби за владу впливових політичних акторів. Тому вважаємо українські неконвенційні протести нездатними подолати гібридність інституційної системи.

Навпаки, схильність політичних еліт використовувати мобілізацію масових протестів для досягнення вузькокорпоративних цілей призводить до інституційного утвердження протестної практики боротьби за владу та сприйняття радикалізму як єдиної можливої форми ефективного впливу на владу. Це твердження ілюструє тенденція зростання неорганізованих виступів та посилення неконвенційної складової протестів в Україні внаслідок недовіри до політичних інститутів.

Тому позитивний потенціал протесту в умовах демократизації політичної системи зводимо до здатності ідентифікувати та сприяти розв'язанню соціальних суперечностей. Це вказує на доцільність інституціоналізації та організаційного оформлення конвенційної політичної поведінки та підвищення легітимності демократичного інституту політичної участі.

\section{Бібліографічний список:}

1. Барбер, Б. Сильна демократія: політика учасницького типу. Демократія. Антологія. Київ: Смолоскип, 2005. C. 254-262.

2. Гутман Е. Устрій дорадчої демократії. Демократія. Антологія. Київ: Смолоскип, 2005. С. 327-363.

3. Putnam R. Bowling Alone: America's Declining Social Capital. Journal of Democracy. 1995. Jan. P. 65-78. 
4. Васильчук Є. О. Роль незаконних воєнізованих і збройних формувань в акціях громадянської непокори та військово-політичних конфліктах в Україні. Гілея. 2017. Вип. 123. С. 308-314.

5. Грищенко Н.І. Протестні практики громадян України: характер основних форм прояву. Регіональні cmydii. Ужгород: Ужгородський національний університет, 2018. Вип.15. С. 12-15.

6. Зеленько Г. Політичні протести зими 2013-2014 років в Україні: зміст, форми, наслідки. Наукові записки. - 2014. - № 2(70). - С.34-55.

7. Колодій А. Соціальний капітал і політична участь громадянина в епоху змін. Biдповідальність християнина у сучасному суспільстві. Матеріали 7-го Екуменічного соціального тижня. (29 вересня 4 жовтня 2014 р. м. Львів). 2014. С. 34-38.

8. Романюк А. Порівняльний аналіз основних форм політичної участі громадян країн Західної Свропи. Віче. 2008. №1. С. 44-47.

9. Революція на граніті 1990 року: яким був перший український Майдан / 24 канал. 2 жовтня 2019 URL: https://24tv.ua/revolyutsiya_na_graniti_1990_prichini_naslidki_uchasniki_foto_n1213193 (дата звернення 15 травня 2020).

10. Постанова Верховної Ради УРСР Про розгляд вимог студентів, які проводять голодування в м. Києві з 2 жовтня 1990 року від 17.10.1990. URL: https://zakon.rada.gov.ua/laws/show/402-12 (дата звернення 15 травня 2020).

11. За Україну без ... фанатизму. Украӥнська правда. 25 лютого 2001 р.

URL: https://www.pravda.com.ua/news/2001/02/25/2981975/ (дата звернення 15 травня 2020).

12. Freedom in the World 2010. Global Erosion of Freedom / Freedom House.

URL: https://freedomhouse.org/report/freedom-world/2010/global-erosion-freedom (дата звернення 15 травня 2020).

13. World Press Freedom Index 2010 / Reporters without border.

URL: https://rsf.org/en/world-press-freedom-index-2010 (дата звернення 15 травня 2020).

14. The Democracy Index 2011: Democracy under stress. URL: https://www.eiu.com/public/topical_report.aspx? campaignid=DemocracyIndex2011 (дата звернення 15 травня 2020).

15. Шаповалов С. Скільки громадян прийде на виборчі дільниці влітку? / "Демініціативи".

URL: https://www.pravda.com.ua/articles/2019/07/17/7221112/ (дата звернення 15 травня 2020).

16. Хилько М.I. Сепаратизм: походження, сутність, різновиди. Гілея. 2019. №144. С. 128-133.

17. Громадянське суспільство України: сучасні практики та виклики розвитку : аналіт. доповідь; за заг. ред. О. А. Корнієвського, Ю. А. Тищенко, В. М. Яблонського. К. : НІСД, 2018. 128 с

\section{References:}

1. Barber B. Syl'na demokratiya: polityka uchasnyts'koho typu. Demokratiya. Antolohiya. Kyiv: Smoloskyp, 2005. S. 254-262.

2. Gutman, E. Ustriy doradchoyi demokratiyi. Demokratiya. Antolohiya. Kyiv: Smoloskyp, 2005. S. $327-363$.

3. Putnam R. Bowling Alone: America's Declining Social Capital. Journal of Democracy. Jan. 1995. P. 65-78.

4. Vasil'chuk C. O. Rol' nezakonnih vo€nizovanih i zbrojnih formuvan' v akcijah gromadjans'koï nepokori ta vijs'kovo-politichnih konfliktah v Ukraïni. Gileja. Vip. 123. 2017. S.308-314.

5. Grishhenko N.I. Protestni praktiki gromadjan ukraïni: harakter osnovnih form projavu. Regional'ni studiï. Uzhgorod: Uzhgorods'kij nacional'nij universitet Vip.15. 2018. S. 12-15.

6. Zelen'ko G. Politichni protesti zimi 2013-2014 rokiv v Ukraïni: zmist, formi, naslidki. Naukovi zapiski. 2014. № 2(70). S. 34-55.

7. Kolodiy A. Sotsial'nyy kapital i politychna uchast' hromadyanyna v epokhu zmin. Vidpovidal'nist' khrystyyanyna u suchasnomu suspil'stvi. Materialy 7-ho Ekumenichnoho sotsial'noho tyzhnya. (29 veresnya 4 zhovtnya 2014 r. m. L'viv). 2014. S. 34-38.

8. Romanyuk A. Porivnyal'nyy analiz osnovnykh form politychnoyi uchasti hromadyan krayin Zakhidnoyi Yevropy. Viche. 2008. №1. S. 44-47.

9. Revoljucija na graniti 1990 roku: jakim buv pershij ukraïns'kij Majdan / 24 kanal. 2 zhovtnja 2019

URL: https://24tv.ua/revolyutsiya_na_graniti_1990_prichini_naslidki_uchasniki_foto_n1213193

10. Postanova Verhovnoï Radi URSR Pro rozgljad vimog studentiv, jaki provodjat' goloduvannja v m. Kiєvi z 2 zhovtnja 1990 roku vid 17.10.1990 URL: https://zakon.rada.gov.ua/laws/show/402-12

11. Za Ukraïnu bez ... fanatizmu/Ukraïns'ka pravda. 25 ljutogo 2001 r.

URL: https://www.pravda.com.ua/news/2001/02/25/2981975/

12. Freedom in the World 2010. Global Erosion of Freedom / Freedom House.

URL: https://freedomhouse.org/report/freedom-world/2010/global-erosion-freedom

13. World Press Freedom Index 2010 / Reporters without border.

URL: https://rsf.org/en/world-press-freedom-index-2010

14. The Democracy Index 2011: Democracy under stress. URL: https://www.eiu.com/public/ topical_report.aspx?campaignid=DemocracyIndex 2011

15. Shapovalov S. Skil'ki gromadjan prijde na viborchi dil'nici vlitku? / "Deminiciativi". 2019.

URL: https://www.pravda.com.ua/articles/2019/07/17/7221112/ 
16. Hil'ko M. I.. Separatizm: pohodzhennja, sutnist', riznovidi // Gileja. 2019. №144. S. 128-133.

17. Gromadjans'ke suspil'stvo Ukraïni: suchasni praktiki ta vikliki roz-vitku : analit. dopovid' / [Jablons'kij V. M., Andriuchenko T. V., Bekeshki-na I. E. ta in.] ; za zag. red. O. A. Korniєvs'kogo, Ju. A. Tishhenko, V. M. Jablon-s'kogo. K. : NISD, 2018. 128 s.

\section{Haponenko V. A. Unconventional forms of protest in Ukraine: mechanism of institutional change or manipulative technology?}

The article deals with the peculiarities of non-conventional protest in democratization of the Ukrainian political system. The controversial role of political participation has been described as a mechanism of influencing the state authorities, driving force of reforms and, at the same time, a technology of manipulating masses, and a consequence of the struggle for power among the influential political actors. The ability of non-conventional protest to promote the transformation of a hybrid institutional system has also been analyzed.

The tendency of political elites to use mobilization of mass protests in achieving their narrow corporate goals as well as dependence of the success of protests on the will of the political elite representatives have been proved. The institutional approval of the protest practice in the struggle for power has been substantiated. It has been pointed out that there is a tendency for increasing unorganized demonstrations and strengthening the non-conventional component of protests in Ukraine due to distrust in political institutions.

The reasons and consequences of the large-scale non-conventional protests in the history of Ukraine have been considered in the context of their impact on the democratization of the political system. The nature of institutional changes arising from people's protests has been described as superficial and indeterminate, for the most part contributing to a change of government, and a temporary relief in social tensions. Instead, the institutional system has undergone little change, asserting non-conventional protest as the only possible option of effective political participation.

The main reasons for the periodic recurrence of non-conventional mass protests are their institutionally-caused nature and their perception as an effective and standardized technique of influencing the government.

Key words: political participation, political system, democratization, institutional change, political protest, civil disobedience, non-conventional protest. 